\title{
EFFECT OF CERTAIN PLANT EXTRACTS AS AN ANTIFEEDANT ON BIOCHEMICAL AND BIOTIC POTENTIAL OF THE EUROPEAN CORN BORER
}

\author{
EL-HEFNY, AMANY S.
}

\author{
Plant Protection Research Institute, ARC, Dokki, Giza
}

(Manuscript received 23 January 2013)

\begin{abstract}
Leaves of bestachia and dedonia plants were extracted using two solvents, water and acetone at two concentrations $5 \& 10 \%$, and tested under laboratory conditions $\left(32 \pm 2{ }^{\circ} \mathrm{C}, 55-65 \%\right.$ relative humidity) against the third larval instar of the European corn borer, Ostrinia nubilalis (hubn.) [lepidoptera: pyralidae]. Dedonia extract in acetone at $10 \%$ concentration achieved the highest efficacy as antifeedant as well as growth inhibitory for $O$. nubilalis. Among all the extracts bestachia extract in water $10 \%$ recorded the lowest rate in food consumption, while bestachia extract in acetone $10 \%$ was the least efficacy in conversion the ingested food. Dedonia extract in acetone $10 \%$ had the highest effect on larval, pupal and adult durations, pupal weight and percentage of malformed pupae and adults. Some extracts proved to be promising on responses of acetyl choline estrase (Ache), trehalse and protease on $3^{\text {rd }}$ larval instar of $O$. nubilalis. Generally, plant extracts have an effect on the biochemical responses of $O$. nubilalis and subsequently it may be considered to be safe and promising agents for the said pest control.
\end{abstract}

\section{INTRODUCTION}

Maize is one of the most important grain crops in Egypt, as it conforms to wheat in its economic importance. It plays an important role in several important industries in Egypt's economy as corn oil, fructose, sugar and starch production, therefore, it is necessary to find out alternative control methods which are as effective as chemical pesticides in order to avoid the hazards caused to the environment due to the repeated use of traditional chemical insecticides that are used commonly as corn borers control (Tawfik et al., 1974).

The European corn borer Ostrinia nubilalis (Huubn.) [Lepidoptera: Pyralidae] is one of the most important insect pests of corn (Zea mays) in many parts of the world, and considered a serious borer on maize, especially in Egypt, in which it was recorded for the first time by Andress (1912). O. nubilalis causes reduction in yield which was estimated by Sherif and Lutfallah (1991) by $33.6 \%$ for plants grown in July, $25^{\text {th }}$. Also, Semeda, (1993) recorded $13-18 \%$ reduction in maize yield due to O. nubilalis. Also, Yacoub, (2006) found reduction of about (12.5 ardab / feddan). 
The European corn borer larvae attack the growing top of the maize plants (rolled leaves) and the primary or secondary corn ears. Also, the larvae could be found all over the plant, to attack and enter the older ears causing shank feeding and stalk breakage due to tunnel nodes and ear internodes El-Naggar (1997).

The deleterious effects of plant extracts on insects are manifested in several ways including growth retardation (Breurer and Schmidt, 1995) and feeding inhibition (Wheeler and Isman, 2001). In Egypt, Adhatoda. vasica (Bestachia) is mainly cultivated for pharmaceutical purposes (Ahmed et al., 1998), although it is occasionally found as a fence plant around fields and gardens. The bioefficacy of $A$. vasica derived materials against a number of insect species has been earlier demonstrated (Hiremath et al., 1997). Dodonaea viscose (Dedonia) extract in water caused reduction in relative consumption, fecundity, hatchability and adult malformation of S. littoralis (Amany El-Hefny and Yacoub, 2008). IGRs decreased the invertase activity after five days of treatment and caused reduction or increasing in trehalase and invertase activities (Eid, 2002 and Khdr et al., 2005)

The aim of this investigation is to study the efficacy of some plant extracts as antifeedant, growth inhibitor and biochemical effects on 0 . nubilalis larvae. Also, the correlation among these parameters and certain enzymes was studied.

\section{MATERIALS AND METHODS}

\section{Plants used:}

Two plants were chosen in the present experiment to test their antifeedant and growth inhibitory activity against $O$. nubilalis larvae in laboratory. These tested plants species belong to two different plant families. The following table demonstrated the english and scientific name of the plants used, their plant family and the part used.

\begin{tabular}{|l|l|l|l|}
\hline Scientific name & Family & English name & Part used \\
\hline Dodonaea viscoza & Sapindaceae & Dedonia & Leaves \\
\hline Adhatoda vasica & Acanthaceae & Bestachia & Leaves \\
\hline
\end{tabular}

These plants were collected from the area around the Plant Protection Research Institute, Dokki, and some located gardens where there no pesticides were applied.

\section{Antifeedant, consumption and growth formula:}

One hundred thirty five $3^{\text {rd }}$ instar larvae of 0 . nubilalis divided into 3 replicates, 5 larvae for each one. All larvae starved for 3 hours and weighed before the beginning of the experiment. Fresh tender pieces of maize plants were weighed and dipped for 
10 seconds in the different tested extracts. Every larva was weighed daily, also the weights of food, feaces were recorded daily for three days consequently.

All formulas used in this part were calculated according to Sadek (2003).

\section{Antifeedant index (AFI):}

$\mathrm{AFI}=[(\mathrm{C}-\mathrm{T}) /(\mathrm{C}+\mathrm{T})] \times 100$

\section{Efficacy of conversion of ingested food (ECI):}

$\mathrm{ECI}=(\Delta \mathrm{B} / \mathrm{I}) \times 100$

\section{Relative consumption rate (RCR):}

$\mathrm{RCR}=\mathrm{I} / \mathrm{Ba} \mathrm{T}$

\section{Relative growth rate (RGR):}

$\mathrm{RGR}=\Delta \mathrm{B} / \mathrm{Ba} \mathrm{T}$

where $\mathrm{C}$ food consumed (leaves) in the control

T: food consumed (leaves) in the treatment

I: weight of food consumed,

Ba: mean of insect weight during the experiment,

T: feeding period in days,

$\triangle \mathrm{B}$ : change in body weight

\section{Preparation of materials:}

Bestachia and dodonia leaves were washed, spread in shadow untill drying. Fifty grams of leaf powder were mixed with 1000 and $500 \mathrm{ml}$ boiled water for the two concentrations $5 \& 10 \%$, respectively. While for the acetone extract the grounded leaves were mixed with the acetone at ratio $1 \mathrm{gm}$ of leaf powder : $2 \mathrm{ml}$ solvent, blended at high speed in an electric blender for $20 \mathrm{~min}$. then the solvent was evaporated by an electric fan. For water and acetone extracts, all the scientific procedures were carried out before treatments to prepare and adjust the two needed concentrations according to Emara et al., (1994). Finally, extracts were kept at $-4{ }^{\circ} \mathrm{C}$ until they were used

\section{Bioassay studies}

$O$. nubilalis larvae were collected from the field by dissecting untreated maize stems. Obtained larvae were kept in plastic box supplied with fresh tender pieces of maize stems. The larvae were starved before feeding on the treated maize pieces with the different extracts. Larval and pupal durations were recorded. Pupae were weighed and malformed ones were recognized, and the percentage of malformation was recorded. Alive pupae kept in plastic jars until emergence of adult, then mean of adult longevity and malformed moths were counted and their percentages were calculated according to the following formula: 
$\%$ Malformed pupae / adult

$$
=\frac{\text { No. of malformed pupae } / \text { adult in treatment }}{\text { total inspected pupae / adult }} \times 100
$$

\section{Statistical analysis:}

The obtained data of the biological studies were statistically analyzed through Excel program for Windows 7 computer to determine the $F$ value and least significant difference L.S.D. at $0.05 \%$ confidence degree.

\section{Biochemical studies:}

\subsection{Chemicals:}

Bovine albumin standard was purchased from Stanbio laboratory (Texas, USA), Commasie brilliant blue G-250 was from Sigma (Sigma Chemical Co.), Pnicotina (purity 97\%) was obtained from Ubichem Ltd. (Ham pshire), while nicotinamide ademine dinucleotide phosphate (reduced form, NADP. $\mathrm{H}_{2}$ ) was supplied from BDH chemicals Ltd. (Poole, England). The rest of chemicals were of high quality and purchased from commercial local companies.

\subsection{Apparatus:}

Telfon tissue homogenizer (ST-2 Mechanic-Preczyina, Poland) was used to homogenize insects for biochemical analysis in a chilled glass. After homogenation, supernatants were kept in a deep freezer at $-20^{\circ} \mathrm{C}$ till biochemical assays. Double beam ultraviolet / visible spectrophotometer (spectronic 1201, Milton Roy Co. USA) was used to measure absorbance of colored substances or metabolic compounds.

\subsection{Preparation of insects for analysis:}

The insects were homogenized in distilled water $(50 \mathrm{mg} / 1 \mathrm{ml}$ ) Homogenates were centrifuged at 8000 r.p.m. for $15 \mathrm{~min}$ at $5^{\circ} \mathrm{C}$ in a refrigerated centrifuge. The deposits were discarded and the supernatants were kept in a deep freezer till use.

\subsection{Determination of tested enzymes:}

\subsubsection{Acetylcholinesterase determination}

Acetylcholinesterase (Ache) activity was determined according to the method described by Simpson et al., (1964) using acetylcholinebromide (AchBr) as substrate. The reaction mixture contained $200 \mu \mathrm{l}$ enzyme solution. $0.5 \mathrm{ml}$ phosphate buffer $\mathrm{pH} 7$ and $0.5 \mathrm{ml} \mathrm{AchBr}(3 \mathrm{mM})$. The test tubes were incubated at $37^{\circ} \mathrm{C}$ for exactly $30 \mathrm{~min}$. $1 \mathrm{ml}$ of alkaline hydroxylamine (equal volume of $2 \mathrm{M}$ hydroxylamine chloride and $3.5 \mathrm{M}$ $\mathrm{NaOH}$ ) was added to the test tubes. Then $0.5 \mathrm{ml}$ of $\mathrm{HCl}$ ( 1 part of conc. $\mathrm{HCl}$ and 2 parts of $\Delta \mathrm{H}_{2} \mathrm{O}$ ) was added. The mixture was shaken vigorously and allowed to stand for $2 \mathrm{~min} ., 0.5 \mathrm{ml}$ of ferric chloride solution $\left(0.9 \mathrm{M} \mathrm{Fecl}_{3}\right.$ in $\left.0.1 \mathrm{M} \mathrm{HCl}\right)$ was added and 
mixed well. The decrease in $\mathrm{AchBr}$ resulting from hydrolysis by AchE was read at 515 $\mathrm{nm}$.

\subsubsection{Trehalase activity determination}

Digestive enzymes were determined according to the method described by Ishaaya and Swirski (1976) using trehalose, sucrose, and soluble starch as substrates for trehalase, invertase and a- amalyses, respectively. Generally, $20 \mu \mathrm{l}$ of diluted solution was incubated for $10 \mathrm{~min}$ at $30{ }^{\circ} \mathrm{C}$ with $250 \mu \mathrm{l} 3 \%$ trehalose solution and 230 $\mu \mathrm{l}$ phosphate buffer ( $\mathrm{pH} 5.4,0.1 \mathrm{M})$. The reaction was stopped by adding $250 \mu \mathrm{l}$ DNS reagent to each tube in boiling water $5 \mathrm{~min}$. Samples were cooled, diluted with $2.5 \mathrm{ml}$ $\mathrm{H}_{2} \mathrm{O}$ and was read at $550 \mathrm{~nm}$ on Spectronic 1201 (Beckman. USA).

Glucose was used as a standard. Appropriate dilutions of enzyme supernatant were used to obtain a linear production of glucose equivalents.

Generally, for each test, trehalase activity was determined from triplicate analyses of three groups of insects. The enzyme activity was expressed as $\mu \mathrm{g}$ glucose released / min / gm fresh weight.

\subsubsection{Protease activity determination}

Proteolytic activity_was measured as described by Tachell et al., (1972), with some modifications, by measuring the increase in free aminoacids split from substrate protein (albumin), during one hour incubation at $30^{\circ} \mathrm{C}$. The reaction mixture consisted $100 \mu \mathrm{l}$ insect homogenate, $1 \mathrm{ml}$ of $0.1 \mathrm{M}$ phosphate buffer $(\mathrm{PH}=8)$ and $100 \mu \mathrm{l}$ of $0.5 \%$ bovin serum albumin. The reaction was stopped by adding $1.2 \mathrm{ml}$ 20\% TCA (trichloric acetic acid). After standing for $15 \mathrm{~min}$, the mixture was centrifuged at 3000 r.p.m. for 20 min, and the supernatant wwas used for measuring the quantity of the produced amino acids.

Amino acids coloimetrically assayed by ninhydrin reagent according to the method described by Lee and Takabashi (1966). The reaction mixture consisted of $100 \mu \mathrm{l}$ supernatant and $1.9 \mathrm{ml}$ of ninydrin-citrate $(\mathrm{PH}=5.5), 0.2 \mathrm{ml}$ of $0.5 \mathrm{M}$ citrate buffer $(\mathrm{PH}=5.5)$ and $1.2 \mathrm{ml}$ glycerol. The mixture was heated in boiling water bath for 12 min and cooled by tap water. The developed color was read at $570 \mathrm{~nm}$. Zero adjustment was against reagent blank containing everything and $100 \mu \mathrm{l}$ distilled water of the supernatant. $D, L$ alanin was used as the standard and the amino acids were expresses as $\mu \mathrm{g}$ alanine / $\mathrm{min} / \mathrm{g}$.b.wt.

\section{Statistics:}

All experiments contained $3-4$ replicates (insect homogenate) and the results of biochemical were determined. The results were analyzed by one - way of variance (ANOVA) using costat statistical software (cohort software, Berkeley). When 
the ANOVA statistics were significant $(p<0.01)$. means were compared by the Duncan's multiple range test.

\section{RESULTS AND DISCUSSION}

\section{Effects of extracts on antifeedant, food consumption and utilization for $\boldsymbol{O}$. nubilalis larvae:}

\section{1.a. Antifeedant activity (AFI):}

In this experiment, $3^{\text {rd }}$ larval instar of $O$. nubilalis was used to determine the antifeedant activity of the larvae against the tested plant extracts. The results in Table (1) showed the antifeedant index (AFI). It was noticed that the AFI values increase according to the increase of the concentration of the tested plant extracts after 24,48 and 72 hours from the beginning of the experiments that ranged from $5.39-31.14$, $5.55-33.84$ and $8.50-35.75 \%$ after 1, 2 \& 3 days, respectively. Dedonia extract in acetone $10 \%$ caused the highest antifeedant value being $31.14,33.84$ and $35.75 \%$ (33.58\% as mean) for the three consequently days, while the lowest percentage antifeedant value was recorded by bestachia extract in acetone achieving 5.39, 5.55 and $8.50 \%$ (6.48\% as mean)after $1,2,3$ days, respectively.

These results were coincided with that reported by Sadek (2003) who found a significant reduction in the food consumed and a considerable decrease in the larval body weight after offering castor leaves treated with $A$. vasica leaf extract to the $4^{\text {th }} S$. littoralis larval instar. The same author reported that the bestachia crude extract reduced consumption growth, utilization of ingested and digested food.

\section{1. b. Efficacy of conversion of ingested food (ECI):}

As shown in Table (1), the efficacy of conversion of ingested food depends on nutritional differentiation between the extracts used for 0 . nubilalis treated larvae . Values of this parameter varied according to the concentrations of the extracts. Among all these extracts, the bestachia extract in acetone $10 \%$ had the most effect on conversion of ingested food being $12.64 \%$ compared with the maximum value that was achieved from the untreated check (56.94\%). Bestachia extract in acetone $10 \%$ was followed by dedonia extract in acetone $5 \%$ with $13.21 \%$ and Bestachia extract in acetone $5 \%$ (18. 98\%).

\section{1. c. Relative consumption rate (RCR):}

Table (1) showed that all extracts reduced the rate of food consumption. The highest reduction was achieved when the $3^{\text {rd }} 0$. nubilalis larval instar was fed on pieces treated with bestachia extract in water $10 \%$ (1.464 gm / gm / day). The remaining extracts also caused reductions and could be arranged in descending order 
as $1.630,1.834,2.143,2.275$ and $2.681 \mathrm{gm} / \mathrm{gm} /$ day for dedonia extract in acetone $5 \%$ and in water $10 \%$, besatchia extract in water $5 \%$, dedonia extract in water $5 \%$ and bestachia extract in extract acetone $5 \%$, respectively. Finally, bestachia extract in acetone $10 \%$ caused $4.075 \mathrm{gm} / \mathrm{gm} /$ day followed by the control that achieved 5.339 gm / gm / day.

\section{1. d. Relative growth rate (RGR):}

Data in Table (1), showed that the dedonia extract in acetone $10 \%$ caused the lowest growth rate measured as $0.376 \mathrm{gm} / \mathrm{gm} /$ day, followed by dedonia extract in water $10 \%$ being $0.383 \mathrm{gm} / \mathrm{gm} /$ day.

On the other hand, bestachia extract in acetone $10 \%$ caused the highest relative growth rate $0.515 \mathrm{gm} / \mathrm{gm} /$ day in comparison with the control (3.466 gm / gm / day).

Table 1. The effect of extracts on food consumption and utilization by 0 . nubilalis

\begin{tabular}{|c|c|c|c|c|c|c|c|c|}
\hline \multirow{2}{*}{ Treatments } & \multirow{2}{*}{$\%$ conc. } & \multicolumn{4}{|c|}{ AFI (days after treatment) } & \multirow{2}{*}{ ECI \% } & \multirow{2}{*}{$\begin{array}{c}\text { RCR } \\
\mathrm{gm} / \mathrm{gm} / \mathrm{d}\end{array}$} & \multirow{2}{*}{$\begin{array}{c}\text { RGR } \\
\mathrm{gm} / \mathrm{gm} / \mathrm{d}\end{array}$} \\
\hline & & 1 & 2 & 3 & mean & & & \\
\hline \multirow{2}{*}{$\begin{array}{l}\text { Bestachia extract } \\
\text { in water }\end{array}$} & 5 & 20.51 & 20.96 & 22.35 & 21.27 & 19.40 & 2.143 & 0.415 \\
\hline & 10 & 30.11 & 30.44 & 31.05 & 30.50 & 19.31 & 1.464 & 0.439 \\
\hline \multirow{2}{*}{$\begin{array}{l}\text { Bestachia extract } \\
\text { in acetone }\end{array}$} & 5 & 5.39 & 5.55 & 8.50 & 6.48 & 18.98 & 2.681 & 0.50 \\
\hline & 10 & 13.26 & 13.84 & 15.19 & 14.09 & 12.64 & 4.075 & 0.515 \\
\hline \multirow{2}{*}{$\begin{array}{c}\text { Dedonia extract in } \\
\text { water }\end{array}$} & 5 & 9.58 & 12.14 & 16.32 & 12.68 & 30.02 & 2.275 & 0.439 \\
\hline & 10 & 23.15 & 23.53 & 24.92 & 23.87 & 20.91 & 1.834 & 0.383 \\
\hline \multirow{2}{*}{$\begin{array}{c}\text { Dedonia extract in } \\
\text { acetone }\end{array}$} & 5 & 25.56 & 28.07 & 30.06 & 27.89 & 29.54 & 1.630 & 0.481 \\
\hline & 10 & 31.14 & 33.84 & 35.75 & 33.58 & 13.21 & 2.849 & 0.376 \\
\hline Control & - & - & - & - & - & 56.94 & 5.339 & 3.466 \\
\hline
\end{tabular}

AFI : $\quad$ Antifeedant index

ECI: Efficacy of conversion of ingested

RCR: Relative consumption rate

RGR: Relative growth rate 


\section{Effect of tested extracts on biological activity of $\boldsymbol{O}$. nubilalis:}

\section{2. a. On larval duration:}

As shown in Table (2), all extracts with different concentrations caused shortage in the mean of larval duration in comparison with the control of 21 days. The shortest larval duration (10 days) was resulted from dedonia extract in acetone $10 \%$ indicating the severest effect among all the tested extracts. Followed by extracts with intermediate effect for bestachia extract in water $5 \%$ and in acetone $10 \% \& 5 \%$ being 12, 13 and 14 days, respectively. While the remaining extracts had a low effect including dedonia extract in acetone $5 \%$ and in water at $5 \& 10 \%$ and bestachia extract in water $10 \%$ achieving $15,16,17$ and 17 days, respectively.

\section{2. b. On pupal duration:}

Data presented in Table (2) indicated pupal duration periods resulted from larvae feeding on pieces of maize which was treated by different extracts. The shortest period resulted from untreated maize (7 days).

Out of all the treatments, dedonia extract in acetone $10 \%$ and bestachia extract in water $5 \%$ led to the longest pupal duration with means 14 and 11 days, respectively, followed by bestachia extract in acetone 5\% (10.25 days). The treatments of bestachia extract in water $10 \%$ and dedonia extract in water $5 \%$ recoded the same pupal duration 10 days for both of them. Similarly, bestachia extract in acetone $10 \%$, dedonia extract in water $10 \%$ and in acetone $5 \%$ all recorded 9 days as the least period after control.

\section{2. c. On pupal weight:}

Data in Table (2) indicated that all extracts caused reduction in the pupal weight averaged from 0.03142 to $0.08547 \mathrm{gm} /$ pupa opposed to $0.12002 \mathrm{gm}$ for the control. The highest efficacy on pupal weight was recorded for the treatment of dedonia extract in acetone $10 \%$ showing $(0.03142 \mathrm{gm} / \mathrm{pupa})$ followed by bestachia extract in water $5 \%(0.04657 \mathrm{gm})$, dedonia extract in acetone $5 \%(0.05178 \mathrm{gm})$, dedonia extract in water $10 \%(0.0634 \mathrm{gm})$ and bestachia extract in water $10 \%$ ( $0.07515 \mathrm{gm} / \mathrm{pupa})$. Finally, the lowest effect on pupal weight was due to bestachia extract in acetone $5 \& 10 \%$ causing 0.08465 and $0.08547 \mathrm{gm} /$ pupa, respectively.

\section{2. d. On Pupal malformation:}

Data presented in Table (2) clearly indicated that percentages of malformed pupae resulted from extracts treatment showed different rates of malformation. Malformed pupae showed indentations at the ventral side, also cavities in head and thorax regions. Last instar of larvae failed to moult seem to shrink and moulting integument of last instar remaining in end of abdominal region. 
Table 2. Effect on mean 0 . nubilalis larval, pupal duration and pupal weight and on the percentage of pupal \& adult malformation due to plant extracts treatments.

\begin{tabular}{|c|c|c|c|c|c|c|c|}
\hline Treatment & $\%$ conc & $\begin{array}{l}\text { Larval } \\
\text { duration }\end{array}$ & $\begin{array}{l}\text { Pupal } \\
\text { duration }\end{array}$ & $\begin{array}{l}\text { Pupal } \\
\text { weight }\end{array}$ & $\begin{array}{c}\% \text { Pupal } \\
\text { malformation }\end{array}$ & $\begin{array}{c}\% \text { Adult } \\
\text { malformation }\end{array}$ & Adult longevity \\
\hline \multirow{2}{*}{ Bestachia extract in water } & 5 & 12 & 11 & 0.04657 & 29.25 & 35 & 9.5 \\
\hline & 10 & 17 & 10 & 0.07515 & 25.8 & 20.25 & 9.0 \\
\hline \multirow{2}{*}{ Bestachia extract in acetone } & 5 & 14 & 10.25 & 0.08465 & 25.0 & 25 & 10.5 \\
\hline & 10 & 13 & 9.00 & 0.08547 & 19.25 & 24 & 11.5 \\
\hline \multirow{2}{*}{ Dedonia extract in water } & 5 & 16 & 10.00 & 0.08115 & 21.0 & 28.25 & 9.50 \\
\hline & 10 & 17 & 9.00 & 0.0634 & 26.0 & 27.5 & 10.0 \\
\hline \multirow{2}{*}{ Dedonia extract in acetone } & 5 & 15 & 9.00 & 0.05178 & 27.8 & 30 & 10.5 \\
\hline & 10 & 10 & 14.00 & 0.03142 & 31.5 & 43 & 8.0 \\
\hline Control & - & 21 & 7.00 & 0.12002 & 8.0 & 18 & 13.87 \\
\hline L.S.D. & & 1.19 & 1.20 & 0.16 & 1.71 & 1.92 & 1.65 \\
\hline
\end{tabular}


The highest significant percentages of malformated pupae were detected in dedonia extract in acetone $10 \%$ (31.5\% malformed pupae). Significant percentages of malformed pupae - in comparison with the control which recorded $8 \%$ - were also obtained from bestachia extract in water $5 \%$ (29.25\%) followed significantly by dedonia extract in acetone $5 \%,(27.8 \%)$, dedonia extract in water $10 \%(26 \%)$ and bestachia extract in water $10 \%(25.8 \%)$, respectively.

On the contrary, bestachia extract in acetone $10 \%$ caused insignificant effect the least percentage of increase in malformed pupae (19.25\%).

\section{2. e. On percentage of malformed adults:}

Fom all the emerged adults, the malformed ones were counted and subsequently and the percentages of malformed moths were calculated, (Table, 2). The malformation included zigzagged wings, wings bending or broken, deformed antennae and abdomen, and also that the adults were unable to fly. The highest percentage of adult malformation (43\%) was obtained as a result of feeding larvae on pieces of maize treated with dedonioa extract in acetone $10 \%$ as compared with the control which showed $18 \%$. This record was significantly followed by bestachia extract in water $5 \%$ and dedonioa extract in acetone $5 \%$ being 35 and $30 \%$ malformed adults, respectively.

The remaining treatments which revealed intermediate effect could be arranged, in descending order, from dedonia extract in water $5 \% \& 10 \%$, and bestachia extract in acetone $5 \& 10 \%$ to bestachia extract in water $10 \%$ achieving $28.25,27.5,25,24$ and $20.25 \%$ malformed adults percent, respectively, (Table, 2).

\section{2. f. On adult longevity:}

Data concerning the adult longevity, after treatment with the tested extracts, indicated that dedonia extract in acetone $10 \%$ caused the highest efficacy averages ( 8 days) compared with the control (13.87 days), while the remaining treatments achieved averages ranging from 9 to 11.5 days for bestachia extract in water and in acetone them at $10 \%$ for both.

It can be noticed that the results obtained in this study are in agreement with that of Abdel-Aziz et al., (1994), in which they found that the aqueous extracts of dedonia gave the highest larval mortality reduction in population and fecundity when it was tested on S. littoralis. This was also, supported by the finding of El-Din and ElGengaihi (2000) who evaluated dedonia plant extract in the laboratory against $S$. littoralis in which the mortality, at the end of the larval stage, was $90 \%$ and $100 \%$ for the pupal mortality at $5 \%$ concentration of the tested extract. Also, Sadek (2003) stated that the toxicity of bestachia extract was manifested by high mortality in which it reduced growth rates and low weight gained by $S$. littoralis larvae fed on the diets 
containing bestachia extract ( $200-2000 \mathrm{ppm})$. No larvae survived to pupation under later concentration.

\section{Biochenical studies:}

\section{3.a. Acetylcholine esterase (Ache) assessment:}

Acetylcholine esterase (Ache) levels were determined for the $3^{\text {rd }}$

O. nubilalis larval instar treated with certain extracts. Data in Table (3) showed that dedonia extract in acetone $10 \%$ achieved, as average, $17.69 \mu \mathrm{g}$ glucose / min / g.b.wt., while, the average of bestachia extract in water $10 \%$ was $60.37 \mu \mathrm{g}$ glucose / $\min /$ g.b.wt.. On the other hand the untreated larvae showed $17.89 \mu \mathrm{g}$ glucose / min / g.b.wt.

\section{3.b. Trehalse assessment:}

The results in Table (3) showed that there was variation in the rates of trehalse when the $3^{\text {rd }}$ larval instar of $O$. nubilalis was treated with the different plant extracts, as opposite results to those obtained from acetyl choline esterase (Ache) assessment. Bestachia extract in water $10 \%$ showed $257 \mu \mathrm{g}$ glucose / min / g.b.wt . On the contrary, bestachia extract in acetone $10 \% \& 5 \%$ achieved the highest mean being 476, 467.6, $\mu \mathrm{g}$ glucose / $\mathrm{min} / \mathrm{g}$.b.wt respectively. For comparison, the control caused $127.33 \mu \mathrm{g}$ glucose / $\mathrm{min} / \mathrm{g}$. b.wt.

\section{3.c. Protease assessment:}

Table (3), results showed similarity to those of trehalase assessment where bestachia extract in water $10 \%$ caused the least mean of the enzyme activity, 10.45 $\mu \mathrm{g}$ glucose, while the same extract in acetone at $5 \%$ concentration caused the highest mean being $27.47 \mu \mathrm{g}$ glucose followed by the control $23.92 \mu \mathrm{g}$ glucose and dedonia extract in acetone $10 \%, 23.83 \mu \mathrm{g}$ glucose.

Table 3. Effect of plant extracts on acetyl choline esterase, trehalase and protease enzymes determined in the $3^{\text {rd }}$ instar larvae of $O$. nubilalis.

\begin{tabular}{|l|c|c|c|}
\hline \multirow{2}{*}{\multicolumn{1}{|c|}{ Treatments }} & \multicolumn{3}{c|}{ Mean $(\mu \mathrm{g}$ glucose / min / g.b.wt) } \\
\cline { 2 - 4 } & AchE & Trehalse & protease \\
\hline Bestachia extract in water $10 \%$ & 60.37 & 257.0 & 10.45 \\
\hline Bestachia extract in acetone $5 \%$ & 31.27 & 467.6 & 27.47 \\
\hline Bestachia extract in acetone $10 \%$ & 27.09 & 476.0 & 15.98 \\
\hline Dedonia extract in acetone $10 \%$ & 17.69 & 439.0 & 23.83 \\
\hline Control & 17.89 & 127.33 & 23.92 \\
\hline
\end{tabular}


Table 4. Correlation coefficient between parameter reveal efficiency of extracts against the European corn borer $\boldsymbol{O}$. nubilalis larvae.

\begin{tabular}{|l|c|c|c|}
\hline \multirow{2}{*}{$\begin{array}{c}\text { Parameters } \\
\text { reveal efficacy of } \\
\text { extracts }\end{array}$} & AchE & Protease & trehalase \\
\cline { 2 - 4 } & -0.13231267 & -0.49464330 & 0.22934566 \\
\hline AFI & -0.39019560 & 0.34028396 & -0.8411430 \\
\hline ECI & -0.41148030 & 0.28846320 & -0.8076104 \\
\hline RGR & -0.57049000 & 0.27988192 & -0.3855480 \\
\hline RCR & &
\end{tabular}

\section{Correlation among the studied parameters:}

The relationship among relative growth rate (RGR) and relative consumption rate (RCR) in hand and the different assayed enzymes on the other hand (Table, 4) demonstrated that both of RCR and RGR were inversely proportion with acetyl choline esterase and trehlase recording $r^{2}=(-0.570490,-0.385548)$ and $(-0.4114803,-$ $0.8076104)$, respectively. All enzymes were determined in the larvae of 0 . nubilalis $3^{\text {rd }}$ instar. On the contrary, (RGR) and (RCR) had directly proportion with protease enzyme being $0.2884632,0.27988192$, respectively.

For the acetyl choline esterase (Ache) on and trehlase effects on conversion of ingested food (ECI), data showed inversely proportion as a negative $r^{2}=-$ 0.3901956 and -0.841143 , respectively. On the opposite, the same parameter (ECI) affecting affecting by had a positive $r^{2}$ value being 0.34028396 .

The remaining parameter of antifeedant index (AFI) had a negative relationship with the activity of (AchE) and protease enzymes being $r^{2}=-0.13231267$ and -0.49464330 , respectively. On the contrary, the same parameter (AFI) was directly proportion with the trehalase as $r^{2}=0.22934566$, (Table 4).

In fact carbohydrates, are essential component for insect body where insect can produce and utilize energy or conversion to lipids or proteins. Metabolism of carbohydrates is controlled by trehalase, amylase and invertase enzymes that play an important role in digestion and utilization of carbohydrates by insects (Wyatt 1967). 


\section{REFERENCES}

1. Abdel-Aziz, Shadia and E.A. 1994. Bio-evaluation of Dodonaeaa viscovoza L. Jacq. extracts on the Egyptian cotton leafworm Spodoptera littoralis (Boisd.) as indicated by life table parameter. Annals of Agric. Sci. Cairo, 40(2): 891 - 900.

2. Ahmed, E. S., H. F. Abd El-Mageed and A. M. Ali. 1999. Flavonoids and antimicrobial volatiles from Adhatoda vasica Nees. Pharmaceut. Pharmacol. Letters 9, $52-65$.

3. Amany, S. El-Hefny and Yacoub. 2008. Evaluation of certain aqueous plant extracts as antifeedants against Spodoptera littoralis (Boisd.)and its biological aspects. Egypt J. Agric., Res. 86(6).

4. Andress, A. 1912. Note sur nouveau ravageur du Mais: Pyrausta nubilalis (Hubn) Bull. Soc. Enti d'Egypt, Dec. 20 - 22.

5. Breuer, M. and G. H. Schmidt. 1995. Influence of a short period treatment with Melia azadarach extract on food intake and growth of the larvae of Spodoptera frugiperda (J. E. Smith) (Lep., Nocutidae). J. Plant Diseases Protection 102, 633 -654 .

6. Eid, A.M. 2002. Esterases and phosphatase in relation to chlorpyrifos resistance in S. littoralis. Egypt, J. Appl. Sci., 17(2): 275 - 284.

7. El-Din, M.M. and S.E. El-Gengaihi. 2000. Joint of some botanical extracts against Egyptian cotton leafworm Spodoptera littoralis (Lepidoptera: Noctuidae). Egyptian J. of Bio. Soc. for Control Pests, 10(1/2): $51-56$.

8. El-Naggar, M.A.Z. 1997. Further studies on greater sugar cane borer Sesamia cretica Led. and European corn borer 0 . nubilalis Hub. Ph.D. Thesis, Fac. Of Agric. Minoufia Univ., Egypt, 152 pp.

9. Emara, M.M., A.G. El-Sisi and S.A. Mahmoud. 1994. Formulation and evaluation of certain local natural products against Varroa, a mite infesting bee colonies. J. Agric. Sci. Mansoura Univ., 19(5): 1843 - 1850.

10. Hirmath, I.G., Y.J. Abn and S.I. Kim. 1997. Insecticide activity of Indian plant extracts Nilaparvatalugens (Homoptera: Delphacidae), Appl. Entomol. Zoll., (32) $159-166$.

11. Ishaaya, I. and E. Swirski. 1976. Trehalase, invertase and amylase activities in the black scale Saissetia oleae, and their relation to host adaptability. J. Insect Physiol. 22: 1025-1029.

12. Khdr, M.M.A., W.M.H. Desuky, J.M.A. El-Shakaa and S.I.Y. Khalil 2005. Toxicological and biochemical studies on the effect of some insect growth 
regulators on Spodoptera littoralis (Boisd.) larvae. Egypt J. Agric. Res., 83(2): $539-561$.

13. Klepzigand, K.D. and F. Schlyter. 1999. Laboratory evaluation of plant extracts derived antifeedants against the pie weelvil Hylobius abietis (Coleoptera: Curculioidae). J. Econ. Entomol. 92: 644 - 650.

14. Lee, y. P. and T. Takabashi. 1966. An improved colorimetric determination of amino acids with the use of ninhydrin. Analyt. Biochem. Vol. (14): 71 - 77.

15. Sadek, M., M., 2003. Antifeedant and toxic activity of Adhatoda vasica leaf extract against Spodoptera littoralis (lep. Noctuidae). Appl. Ent. 127(1): 396 404.

16. Semeda, A.M., Ismail, I. I. and A. A. Sharaf El-Din. 1993. Effect of plant density of maize on the inspection with some insect pests and resulting yield loss. Bull Fac. Of Agric. Cairo Univ., 44(2): 477 - 487.

17. Sherif, M.R. and A.F. Lutfallah. 1991. Assessment of losses in yield due to infestation by Ostrinia nubilalis (Hubner) in Egypt (Lepidoptera: Pyralidae). Bull. Ent. Soc. Egypt, 70: 25 - 30.

18. Simpson, D.R., D.L. Bulland and D.A. Linquist (1964). A semimicrotechnique for estimation of cholinesterase activity in Boll weedils. Ann. Ent. Soci. Amer., 57: $367-371$.

19. Tachell, R. J., S. F. Araman and F. N. Boctor. 1972. Biochemical and physiological studies of certain Ticks (Ixodoidea) Z. Parsitenk. Vol. 39: 345 350.

20. Tawfik, M.F.S., M.T. Kira and S.M.I. Metwally. 1974. On the abundance of major pests and their associated predators in corn plantations. Bull. Soc. Ent. Egypt, 58, pp. $167-177$.

21. Wheeler, D.A. and M.B. Isman. 2001. Antifeedant and toxic activity of Trichilia americana extract against the larvae of Spodoptera litura. Entomol. Exp. Appl. 98: $9-16$.

22. Wyatt, G.R. 1967. The biochemistry of sugar and polysaccharides in insect Adv. Insect Physiol. 4: $287-360$.

23. Yacoub, Sh. S. 2006. Efficacy of some plant extracts in controlling Sesamia cretica Led. and Ostrinia nubilalis (Hubn.) in maize fields. Ph. D Thesis, Fac of Agric., Benha University, Egypt.

24. Yacoub, Sh.S., Amany S. El-Hefny, and Rasha A. El-Hosary. 2008. Evaluation of some compounds from plant origin for controlling Sesamia cretica led. in maize under field conditions. Egypt, J. Agric. Res., 86(6): 2207 - 2216. 


\title{
تأثير بعض المستخلصات النباتية كمانعات تغذية على الاقتدار الحيوى والبيوكيميائى لاودة الأرة الأوروبية
}

\author{
أمســي ســامي الحفنى \\ معهز بحوث وقــاية النباتات - مركز البحــوث الزراعيــة - الدقى
}

تم استخلاص أور اق نباتى البستاشيا و الديدونيا بمذيبين مختلفتين المــاء و الاسيتون بتركيـزين

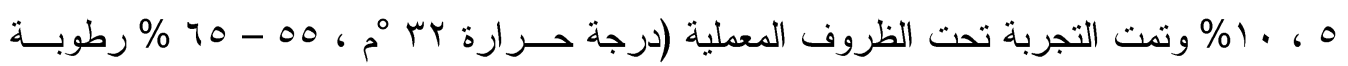

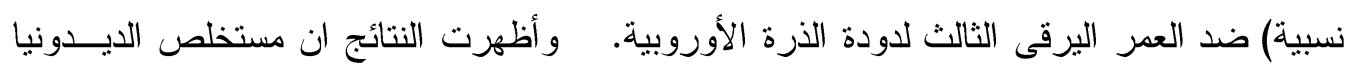

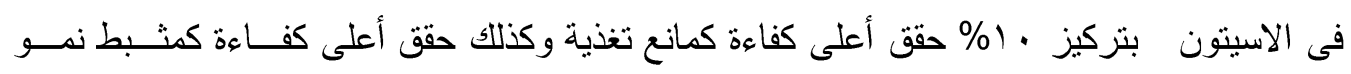

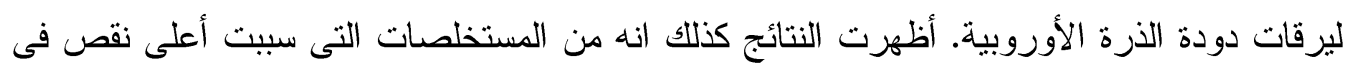
كفاءة الاستفادة من الغذاء المقدم مستخلص البستاشيا فى الماء • (\% سجل أقل معدل استهلاك الغذاء

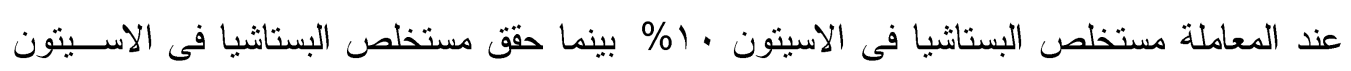

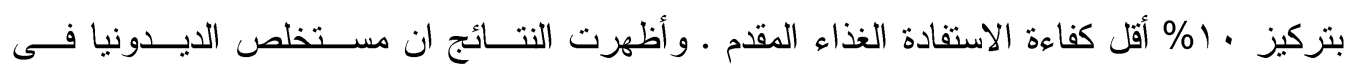
الاسيتون بتركيز · (\% أكثر المستخلصات كفاءة من حيث تأثيرها على طول العمر اليرقى و العمــر

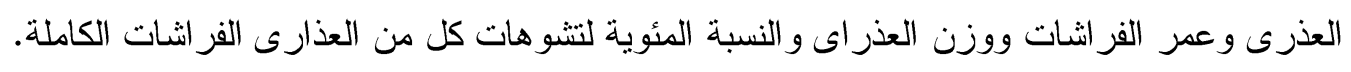

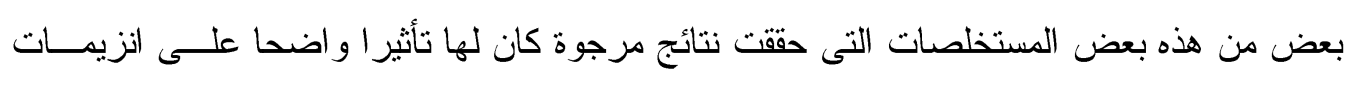
الاستيل كولين استريز و التريهاليز والبروتيز على يرقات العمر اليرقى الثالث لدودة الذرة الأوروبية.

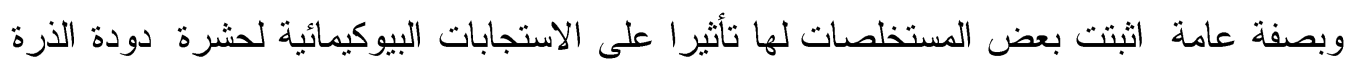
الأوروبية و عليه يمكن اعتبار ها وسيلة واعدة وآمنة فى مكافحة الآفة محل الدراسية. 